\title{
PATTERNS OF SOUND CHANGE IN DEORI AND DIMASA*
}

\author{
Monali Longmailai \& Jonali Saikia
}

This paper compares the two cognate TibetoBurman languages, Deori and Dimasa, in terms ofsound change patterns in certain class of lexical items. In this regard, it discusses the noun categorization devices besides the counting system, some morphological features and the use of borrowingpresent in these languages. The paper, thereby, studies briefly their sociolinguistic context of language loss and retention.

Keywords: Deori, Dimasa, Bodo-Garo, language use and context

\section{Introduction}

Deori and Dimasa belong to the Bodo sub-group of the Bodo-Garo languages from the TibetoBurman language family. Deori is spoken in the northern and eastern parts of Assam, mainly, the districts of Sonitpur, Lakhimpur, Dhemaji, and few others (nearly 28,0000 people according to 2001 census), whereas Dimasa is spoken in the central and southern parts, i.e. Hojai, KarbiAnglong, DimaHasao and Cachar districts in Assam and Dimapur district in Nagaland (100,000 approximately according to 2001 census). ${ }^{1}$ The number of speakers is less than the number of people in case of Deori, while it is equal in Dimasa. $^{2}$ While Deori is definitely endangered, Dimasa is vulnerably endangered as can be estimated from the UNESCO Report. There have been few works on both the languages among which, these are significant: descriptive grammar

\footnotetext{
* The authors would like to acknowledge the Deori informants of Bor-Deorigaon village, Lakhimpur district, Assam, and the Dimasa community for their help and assistance in collecting wordlist across several years of personal researches of both the authors, and finally the reviewers and editors of the paper, without whose comments and feedback, the present work would have been incomplete.

${ }^{1}$ Deori and Dimasa populations are unavailable currently in the 2011 Census of India report.

${ }^{2}$ Ethnologue 2019 mentions 50,000 as ethnic population of Deori.
}

of Deori and DimasabyJacquesson (2005, 2008), Nath's sound change on Deori(2012), Singh's (2001) Dimasa phonology and morphology, andLongmailai's (2014) Morphosyntax of Dimasa,although comparative study of Deori and Dimasa is not known.

The main aim of this paper is to provide a comparative study between the two cognate languages, Deori and Dimasa in terms of sound change patterns in certain class of lexical items. In this concern, it discusses the noun categorization devices highly present in these languages. For instance, $\mathrm{mV}$ - is the category prefix for names of animals in Bodo-Garo languages, and hence, me$s i$ 'deer' in Deori morphologically resembles the Dimasa counterpart mi-fi. However, Deori $u t^{h} u$ 'hand' is lexically divergent from the Dimasajau. It also investigates the counting system, similarities in the morphological features and lexical set, the use of borrowing in both the languages and thereby, studies briefly their sociolinguistic context of language loss and retention.

\subsection{Overview of Deori and Dimasa}

The Deori (exonym) people are one of the indigenous ethno-linguistic groups of North-East India. They identify themselves as Jimosaya (endonym) meaning 'sons of nature (sun and moon)'.The Deori languages can be subdivided into four dialects- Dibongiya, Tengaponiya, Borgiya and Patorgiya. Dibongiya is the standard variety, which is spoken mostly in Bor-Deori village of Narayanpur, Lakhimpur district of Assam.

Dimasas are one of the most colourful and multicultured people in North-East India. They have a rich history with interesting folklores, wellpreserved rituals and practices. The term 'Dimasa' (endonym) means 'sons of the great river' where 'di' means 'water, 'ma' means 'big and 'sa' means 'sons' (Singha 2007:1). Literally, they are called 'sons of the mighty Brahmaputra river' but

Nepalese Linguistics, vol. 34, 2019, pp. 26-35. 
the more probable meaning could be 'sons of the river Dhansiri or Dima (big river)', the place where their first capital 'Dimapur' was established in the later part of the eleventh century (Barman 2007). It has four major dialects: Hasao, Hawar, Dembra and Dijuwa of which, Hasao is adopted as the standard dialect.Figure 1 shows the Deori speaking region in upper circle and Dimasa in lower circle.

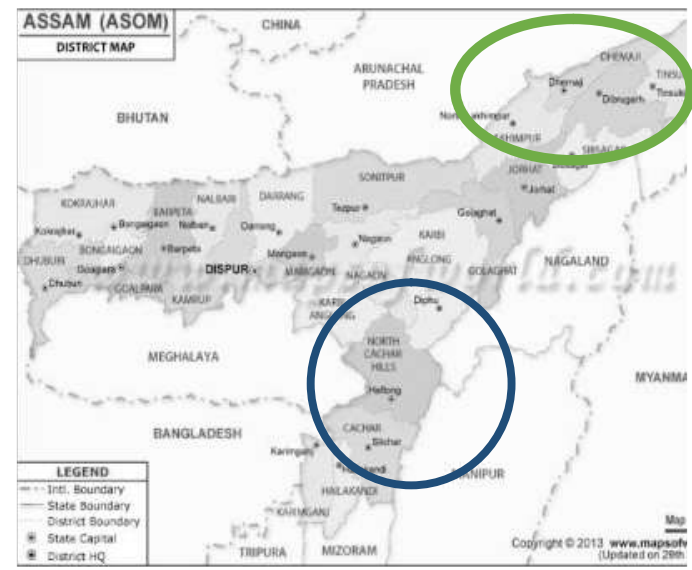

Figure1: Deori and Dimasa speaking region

Figure 2 shows the genealogical classification of Deoriand Dimasaas a branch of the TibetoBurman family.
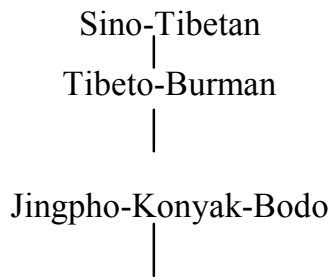

Konyak-Bodo-Garo

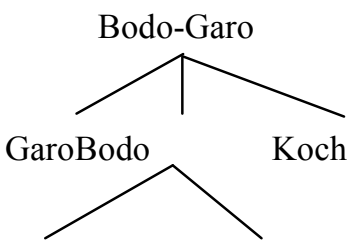

Deori

Dimasa

Figure 2: Genetic classification of Deoriand Dimasabased on SIL Ethnologue(2019)

\subsection{Typological Features of Deori and Dimasa}

Deori and Dimasa have both SOV word orders. They have agglutinating features, and are mostly suffixing. Both the languages are lexically tonal having three distinctions- high, mid and low. The tones are also register tones.It also has open syllabic structure. The sentence constructions end in falling intonation in the languages with mostly trochaic word accents. This is a typical suprasegmental feature of the Bodo-Garo languages which share similar features with some of the Austro-Asiatic languages.

\subsection{Methodology}

Data for the present study are from domain-based word lists such as flora and fauna, numerals, kinship, body parts. For Deori, it was collected from Bor-Deorigaon village of Lakhimpur district. For Dimasa, the co-author of the paper, MonaliLongmailai, being a native speaker of Dimasa and a linguist, provided data from her knowledge as well as consulted from few informants at Haflong, DimaHasao district, Assam. Approximately, 1000 words were collected out of which some hundred words have been chosen for illustration here for our analysis and observations.

\section{Lexical cognates in Deori and Dimasa}

The Bodo sub-group from the Bodo-Garo branching of the Tibeto-Burman language family (see Figure 1) includes Bodo/Boro, Tiwa, Dimasa, Kokborok and Deori (Post \& Burling 2017) among which, Dimasa,Bodo, Tiwa and Kokborokare more genetically related, while Deori is more distant from these related languages.Eberhard, Simons and Fennig in the Ethnologue (2019) list the lexical similarity of Deori with Boro as a meagre $11-16 \%$ unlike 77 93\% lexical similarities of Deoriwith its varieties. For instance, the word for water in these languages are $d_{I}$ (Dimasa), $d u I$ (Bodo), $t I$ (Tiwa) and $t_{I}$ (Kokborok) while in Deori, it is $d_{3 I}{ }^{3}$ Burling (2012), in Post \& Burling (2017), mentions the

\footnotetext{
${ }^{3}$ The date for lexemes for 'water' from Bodo group of languages, are illustrated, based on the authors' previous knowledge while working with various informants from these languages.
} 
28 / Patterns of sound...

large number of lexical cognates among these related languages, while Deori is the most divergent of all. He further adds that Deori has lost syllable final stops and most nasals unlike the retained forms in the remaining languages, which will be seen in the analysis presented in the paper.

Further, the linguistic mapping of the Bodo group of languages is spread from the west of Assam across the Brahmaputra river (Bodo) to below the river basin towards southeast (Tiwa) and southeast (Dimasa)) with Kokborokfurther in the south (state of Tripura) in northeast India, Deori, on the other hand, is isolated above the river basin in the central and north-eastern part of Assam with the neighbouring Tani languages (Tibeto-Burman) and Tai-Kadai languages.Bodo and Tiwa are closer to each other, and Dimasa is closer to Kokborok henceforth. Both the languages, Deori and Dimasa, are,thus, lexically more divergent than convergentprobably, both because of linguistic mapping and differences in areal contact, as will be observedwith the help of the subsequent morph-phonemic (section 2.1) especially, vowel and consonant alternations, syllable alternation, deletion, and aspiration and voicing contrasts, and morphological analysis (sections 2.2, $2.3 \& 2.4$ ) which focuses mainly on noun categorization, morphological prefixes and suffixes and lexical resemblances, (few accidental similarities of Deoriwith the Dijuwa dialect of Dimasaspoken in the eastern part needs a serious study in future research).

Table 1 shows the lexemes which are highly similar, while Table 2 shows the moderately similar words with morpho-phonological differences, which is also the core study of the paper.

Table 1:Highly similar words

\begin{tabular}{|l|l|l|}
\hline Deori & Dimasa & Gloss \\
\hline jon & jon & 'insect' \\
\hline gando & gando & 'pillow' \\
\hline dini & dini & 'today' \\
\hline mja & mja & 'yesterday' \\
\hline la & la & 'take' \\
\hline
\end{tabular}

Table 2: Similar words in Deori and Dimasa

\begin{tabular}{|c|c|c|}
\hline Deori & Dimasa & Gloss \\
\hline saba & limbafaba & 'disease' \\
\hline dUSIrI & daup $p^{\mathrm{h}} \Gamma I$ & $\begin{array}{l}\text { 'pigeon' } \\
\text { (also daufart in } \\
\text { Dimasa) }\end{array}$ \\
\hline Iba & bas & 'bloom' \\
\hline $\begin{array}{l}\text { dekagu } \\
\text { (Assametized } \\
\text { with deka) }\end{array}$ & $\begin{array}{l}\text { naga, } \\
\text { nagafa }\end{array}$ & 'young man' \\
\hline samat $\int \mathrm{I}$ & dama & 'butterfly' \\
\hline dzI & $\mathrm{dI}_{\mathrm{I}}$ & 'water' \\
\hline $\mathrm{p}^{\mathrm{h}} \mathrm{d}_{3 \mathrm{I}}$ & gdzav & 'gold' \\
\hline jẽ & waI & 'fire' \\
\hline
\end{tabular}

Table 3, on the other hand, shows the complete set of dissimilar words present in these two languages.

Table 3: Highly dissimilar words

\begin{tabular}{|c|c|c|}
\hline Deori & Dimasa & Gloss \\
\hline$\tilde{\mathrm{ja}}$ & dain & 'moon' \\
\hline ja & dain & 'month' \\
\hline$\tilde{\mathrm{ja}}$ & ha & 'land' \\
\hline nanoma & grain & 'dry' \\
\hline ZItI & nonıma & 'lizard' \\
\hline $\mathrm{t} \tilde{\mathrm{f}} \mathrm{ija}$ & na? & 'fish' \\
\hline midige & alv & 'cat' \\
\hline lepedor & bron & 'goat' \\
\hline so & hono & 'pig' \\
\hline semesi & $\mathrm{k}^{\mathrm{h}}$ arfin & 'ant' \\
\hline grja & bre & 'bee' \\
\hline
\end{tabular}

2.1 Sound changes in Deori and Dimasa lexical cognates

This section discusses common sound changes found in Deori and Dimasa such as, alternations of vowel and consonant, and syllable alternation, monophthongization, aspiration, voicing, and deletion. It also highlights the feature of consonant cluster and syllable structure between these two languages.

\subsubsection{Vowel Alternation}

Vowel Alternation occurs irregularly across these two languages. However, few common changes have been listed in Table 4 based on the findings. 
Table 4: Vowel alternation in Deori and Dimasa

\begin{tabular}{|c|c|c|c|}
\hline $\begin{array}{l}\text { Vowel } \\
\text { alternation }\end{array}$ & Deori & Dimasa & English \\
\hline $\mathbf{p} \sim \mathbf{a} \boldsymbol{d}$ & moms & $\begin{array}{l}\text { amaofa, } \\
\text { mamav }\end{array}$ & 'nephew' \\
\hline $\boldsymbol{\partial} \boldsymbol{U} \sim \mathbf{a}$ & morsa & mja?, mja $a \mathrm{a}$ & 'boy' \\
\hline $\mathbf{0} \sim \mathbf{a}$ & botor & bat ${ }^{\mathrm{h}} \mathrm{\partial r}$ & 'weather' \\
\hline $\mathbf{I} \sim \mathbf{a}$ & SIfI & hor, farI & 'night' \\
\hline $\mathbf{I} \sim$ aI & $\begin{array}{l}\text { midıgI- } \\
\text { ra, } \\
\text { midI }\end{array}$ & $\begin{array}{l}\text { mdaI/mədaI, } \\
\text { mdai/mədaI, } \\
b^{h} \mho t\end{array}$ & $\begin{array}{l}\text { 'God, } \\
\text { ghost' }\end{array}$ \\
\hline $\begin{array}{l}\mathbf{e} \sim \mathbf{I}, \\
\mathbf{a} \sim \mathbf{I}\end{array}$ & $\operatorname{met} \int \mathbf{a}$ & $\mathrm{mI} \int \mathbf{I}$ & 'tiger' \\
\hline $\boldsymbol{U} \sim \boldsymbol{J}$ & kobolon & 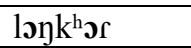 & 'hole' \\
\hline $\boldsymbol{\sigma a} \sim \mathbf{a} \boldsymbol{0}$ & doa & $\mathrm{d} \mathbf{a} \boldsymbol{0}$ & 'bird' \\
\hline
\end{tabular}

From the above Table,it can be seen thatthe vowel alternation in Deori and Dimasa is irregular.That is, $/ \mathrm{J} /$ in Deori corresponds to/av/ in Dimasa, and /o/ with /a/ (o>av, a/ \#,),/ov/ with /a/ and/I/ with /a/ (ov, I>a/_\#),/I/ with /aI/ (I>aI/_\#), /e/ with/I/ and/a/with /I/ $(\mathrm{e}, \mathrm{a}>\mathrm{I} / \#), / \mathrm{v} /$ with $/ \overline{\mathrm{o}} /(\mathrm{v}>\mathrm{s} / \#), / \mathrm{ua} /$ with/av/ (va>av/_\#), and so on.

\subsubsection{Monopthongization}

Deori has the monophthongization of the sounds $/ \mathrm{J} /$ and $/ \mho /$ that are present in Dimasa as diphthong as in $/ a v /$, which is exemplified inTable 5;

Table 5: Monopthongization in Deori and Dimasa

\begin{tabular}{|c|c|c|}
\hline Deori & Dimasa & Gloss \\
\hline tw & $\mathrm{t}^{\mathrm{h}} \mathbf{a} \boldsymbol{U}$ & 'oil' \\
\hline məmว & amaofa, mamav & 'nephew' \\
\hline momosi & $\operatorname{ama} \int \mathrm{I}$, mamav & 'niece' \\
\hline $\mathrm{d} \boldsymbol{x}$ & daons & 'hen' \\
\hline doka & daok ${ }^{\mathrm{h}} \mathrm{a}$ & 'crow' \\
\hline SO & fav & 'body' \\
\hline
\end{tabular}

\subsubsection{Metathesis}

Syllable alternation is seen only in few instances, in case of shared innovation in both the languages and they are shown in bold in Table 6 .

Table 6: Metathesis in Deori and Dimasa

\begin{tabular}{|l|l|l|}
\hline Deori & Dimasa & Gloss \\
\hline danoI & nadinI & 'why' \\
\hline goton & bgoy/bogon & 'nose' \\
\hline doa & dao & 'bird' \\
\hline
\end{tabular}

In the given Table, the Deori example gotor for the Dimasa equivalent bog $\delta \eta^{\prime}$ 'nose' also undergoes assimilation, since the alveolar $/ \mathrm{t} /$ and $/ \mathrm{d} /$ are the nearest sounds than the bilabial $/ \mathrm{b} /$ to the velar $/ g /$ when $/ g /$ occurs word initially in the same word, i.e. gotonin place of *gobon.

\subsubsection{Aspiration}

Deori has the absence of aspiration in sounds shared with those having aspiration in Dimasa.In Table 7 , theunaspirated $/ \mathrm{k} /$ and $/ \mathrm{p} /$ in case of Deori alternate as the aspirated $/ \mathrm{k}^{\mathrm{h}} /$ and $/ \mathrm{p}^{\mathrm{h}} /$ in Dimasa.

Table 7: Aspiration in Deori and Dimasa

\begin{tabular}{|c|c|c|}
\hline Deori & Dimasa & Gloss \\
\hline kokom & $\mathbf{k}^{\mathbf{h}_{\text {}}}$ dzema & 'cockroach' \\
\hline doka & davk $\mathbf{k}^{\mathbf{h}} \mathrm{a}$ & 'crow' \\
\hline peno/penoma & $\mathbf{p}^{\text {hain }}$ & 'sell' \\
\hline koma & $\mathbf{k}^{\mathbf{h}} \mathrm{am} / \int \mathrm{a} \sigma$ & 'burn' \\
\hline
\end{tabular}

\subsubsection{Voicing}

Most of the voiced sounds in Dimasa alternate to the voiceless counterparts in Deori. Except for the /g/ in Deori examples such as gosarinalternating with Dimasa $\boldsymbol{k}^{\boldsymbol{h}}$ aîforıma 'earthworm', Deorimostly loses voicing while Dimasa retains the voicing for velar stops in the initial positions, i.e $\mathrm{k}>\mathrm{g} / \mathrm{V}_{-}$.

Table 8: Voicing in Deori and Dimasa

\begin{tabular}{|l|l|l|}
\hline Deori & Dimasa & Gloss \\
\hline gosarın & $\mathbf{k}^{\mathbf{h}}$ aĩforıma & 'earthworm' \\
\hline kıra & grain & 'dry' \\
\hline kon & gnay/gənay & 'rich' \\
\hline
\end{tabular}

\subsubsection{Deletion}

Deletion in the initial and the final word positions/syllables are common for shared words in Deori while only initial deletion has been found among the cognates in Dimasa.

Table 9: Deletion in Deori and Dimasa

\begin{tabular}{|l|l|l|}
\hline Deori & Dimasa & Gloss \\
\hline dzõwa & wa? & 'bamboo' \\
\hline tjudzoba & dzba/dzəba & 'battle' \\
\hline dzeba & hadzarba & 'birth' \\
\hline
\end{tabular}

As shown in Table 9 with the features of initial deletion across these languages, $d$ zõis missing in Dimasawa?'bamboo', although it is unclear, which the proto form is.dzormight be a later insertion in Deori, since most of the TB languages 
30 / Patterns of sound...

have the word for bamboo as wa. Also, a similar sound $t u$ does not occur word-initially in Dimasadzba 'battle'. In the third example, Deori does not use the first syllable ha like Dimasa. In Dimasa, ha means 'soil, land',dzar'shift/transcend' and -bais a nominalizing suffix which literally translates as "state of coming to earth/life". Thus, Deori might have lost the use of the dzalater.

Besides the initial deletion, there is deletion of the sounds in the word final position mostly stops and nasals as also observed in Burling (2012), as well as syllable finally in Deori whereas Dimasa retains these sounds in some of the words, which is shown in Table 10:

Table 10: Final Sound Deletion in Deori

\begin{tabular}{|c|c|c|}
\hline Deori & Dimasa & English \\
\hline$\tilde{\mathrm{sa}}$ & Jain & 'sun' \\
\hline girasi & gradzIk & 'old woman' \\
\hline tgI & $\int \mathrm{I} \int \mathbf{a}$ & 'dog' \\
\hline mijo/ miju & mijon & 'elephant' \\
\hline
\end{tabular}

\subsubsection{Consonant alternation}

Consonant alternation has been noticed in both the languages in few words as in, bote 'murder' which has bilabial $/ \mathrm{b} /$ in the first syllable and alveolar $/ \mathrm{t} /$ in the second syllable, while Dimasa has alternation of $/ \mathrm{b} /$ to the nearest assimilated voiced sound, i.e. the alveolar $/ \mathrm{d} /$ as in $d \partial t^{h} a r$ for the same meaning.

\subsubsection{Liquid alternates / / / /1/}

Deori and Dimasa have alternation of the liquids $/ \mathrm{r} /$ and $/ 1 /$, i.e. in some lexical cognates, what occurs in Dimasa as /1/ in $t^{\text {hallik }}$ 'banana', for instance, occurs in Deori as / $/$ / as in tirI.

Table 11: Liquid alternates in Deori and Dimasa

\begin{tabular}{|c|c|c|}
\hline Deori & Dimasa & Gloss \\
\hline $\begin{array}{l}\text { girimous } \\
\text { a }\end{array}$ & nana gilı & $\begin{array}{l}\text { 'baby'(in } \\
\text { Dimasa, } \\
\text { 'infant') }\end{array}$ \\
\hline merv & mI? & 'animal' \\
\hline$\tilde{1} g v$ & figu & $\begin{array}{l}\text { 'mekhla/skir } \\
\text { t' }\end{array}$ \\
\hline tirI & thailik $^{\text {the }}$ & 'banana' \\
\hline$\widetilde{\tilde{I}}$ & rI? & 'cloth' \\
\hline
\end{tabular}

\begin{tabular}{|l|l|l|}
\hline ḑU & $\begin{array}{l}\text { loy/dzIr } \\
(\text { dzorvinDijuwa/Haw } \\
\text { ar })\end{array}$ & 'call' \\
\hline
\end{tabular}

However, the presence of $/ \mathrm{f} /$ in Dimasa as in $r I$ ? 'cloth' also corresponds to the loss of this sound in the lexical counterparts in Deori besides the syllable deletion as in $\tilde{\imath}$ as observed from Table 11.

\subsubsection{Phonotactics}

Consonant cluster formation is very productive in Dimasa which is present in several Bodo-Garo languages, since it has both onset and pseudo cluster. In case of pseudo cluster, they are sesquisyllabic since the vowel is weakened between the syllables due to shortening. On the contrary, Deori has the absence of consonant cluster.

Table 12: Phonotactics in Deori and Dimasa

\begin{tabular}{|l|l|l|}
\hline Deori & Dimasa & Gloss \\
\hline simI & $\mathbf{J m I}$ & 'needle' \\
\hline gibaba & gbaba & 'vomiting' \\
\hline kına & $\mathbf{k}^{\mathbf{h}}$ na & 'hear' \\
\hline goton & bgon & 'nose' \\
\hline gohonI & gnI & 'two' \\
\hline kon & gnay & 'rich' \\
\hline
\end{tabular}

In Dimasa, the pseudo clusters in the onset position are shown in bold, $/ \int \mathrm{m} /, / \mathrm{gb} /, / \mathrm{k}^{\mathrm{h}} \mathrm{n} /, / \mathrm{bg} /$, /gn/ which are broken obligatorily into a single syllable rather than a cluster, i.e. in Deori, they are simi, not fmi'needle', and grbaba unlike gbaba'vomiting'.

Thus, Deori has more simplified syllable structure than Dimasa, which is shown in Table 13, i.e. the former language tends to be monosyllabic (clipped forms) and has absence of consonant cluster for the same counterparts unlike the latter.

Table 13: Simplified syllables in Deori

\begin{tabular}{|l|l|l|}
\hline Deori & Dimasa & Gloss \\
\hline da & thamp $^{\text {h }}$ I & 'mosquito' \\
\hline simI & $\int \mathrm{mI}$ & 'needle' \\
\hline ka & $\mathrm{gk}^{\text {ha }} / \mathrm{k}^{\mathrm{h} a}$ & 'bitter' \\
\hline meI & $\mathrm{mI} \mathrm{ep}$ & 'buffalo' \\
\hline kira & grain & 'dry' \\
\hline
\end{tabular}




\begin{tabular}{|l|l|l|}
\hline pops & boyp $^{\text {hay }} /$ bov $^{\text {hay }}$ & 'tree' \\
\hline seke & Jigama & 'rat' \\
\hline no & nin & 'you' \\
\hline
\end{tabular}

\subsection{Noun categorization}

Nouns in Deori and Dimasa, like several TibetoBurman languages, are mostly categorized by the lexemes and bound stems either prefixed or suffixed to these roots to belong to a lexical set. Names of flora and fauna, and few others, have lexical compounding in Deori and Dimasa with the free morphemes such as $p$ s $/ p^{h} a \eta^{\prime}$ 'tree/plant', $t_{I} / t^{h} a I^{\prime}$ fruit', $m e / m_{I}{ }^{\text {'}}$ 'animal', which function as both derivational prefixes and suffixes.

Names of fruits have the affixation of $t_{I}$ - in Deori and $t^{h} a^{-}$in Dimasa derived from the lexeme themselves which mean 'fruit'.

Table 14: $t I / t^{h} a I$ in Deori and Dimasa

\begin{tabular}{|c|c|c|}
\hline Deori & Dimasa & Gloss \\
\hline tI-mu & $\left.\mathbf{t}^{\text {hal}} \mathbf{a}-d\right\} u$ & $\begin{array}{l}\text { 'mango' (Lit } \\
\text { 'fruit mango') }\end{array}$ \\
\hline tI-rI & $\mathbf{t}^{\text {haI-lik }}$ & 'banana' \\
\hline tasi-tI & $t^{\text {ha }}$ - $-^{\text {ha }}$ aI & 'potato' \\
\hline setotsI-tI & $\mathbf{t}^{\text {thaI}} \mathbf{a}-\int \mathrm{a}$ & 'lemon' \\
\hline
\end{tabular}

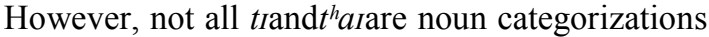
related to fruits. In case of hat in Deori and hat ${ }^{h} a I$ in Dimasa,they mean 'tooth'; they are bases, and cannot be further segmented into morphemes. $t^{h} a I$ in Dimasa is also a nominalizing suffix to derive nouns from verbs as in $h a-t^{h} a I^{\text {' }}$ rainfall pattern (rain-NMZ)' although tris unattested in Deori for the same.

In case of the lexical categorization of trees and plants in Deori, pois reduplicated as a lexeme and during the compounding, while $p^{h} a$ in Dimasa categorization is a reduced form of the lexeme $b o y-p^{h} a \eta$ (wood-tree). Instances of $p o$ in Deori and $p^{h} a y$ in Dimasa are shown in Table 15:

Table 15:ps/phayin Deori and Dimasa

\begin{tabular}{|c|c|c|}
\hline Deori & Dimasa & Gloss \\
\hline роро & $\begin{array}{l}\text { boy-phay/bo- } \\
\text { p }^{\text {hay }}\end{array}$ & $\begin{array}{l}\text { 'tree } \\
(\text { wooden)/plant' }\end{array}$ \\
\hline tImv pops & thardzo-p $^{\text {h }}$ ay & $\begin{array}{l}\text { 'mango tree' } \\
\text { (Lit: 'fruit } \\
\text { mango tree') }\end{array}$ \\
\hline tIfI popo & tharlik-phan $^{\text {ha }}$ & 'banana tree' \\
\hline
\end{tabular}

'lemon tree'

Besides the lexemes functioning as category prefixes, bound forms also are productive during the lexical categorization. Both Deori and Dimasahave this kind of categorization for instance, for animals with the $\mathrm{mV}$ - prefixation. While in Deori, it occurs as me- regularly, the $\mathrm{mV}$ - forms undergo mostly vowel harmony in case of Dimasa as exemplified in Table 16.

Table 16: $\mathrm{mV}$ - prefixation for animalsin Deori and Dimasa

\begin{tabular}{|c|c|c|}
\hline Deori & Dimasa & Gloss \\
\hline me-ru & mI? & 'animal' \\
\hline me-I & mI- $\mathrm{ep}$ & 'buffalo' \\
\hline me-sI & $\mathrm{mI}-\int \mathrm{eI}$ & 'deer' \\
\hline me-suro & mo- - ron & 'fox' \\
\hline me-sa & $m I-\int \mathrm{I}$ & 'tiger' \\
\hline
\end{tabular}

It can be noted thatmV- is a homophonous prefix since it is also used for counting numerals in general, besides names of animals. While Deori uses the $m u$ - form, Dimasa uses the $m a$ - form for the counting as given Table 17:

Table 17:Classifier $\mathrm{mV}$ - for counting numerals (generic) in Deori and Dimasa

\begin{tabular}{|c|c|c|}
\hline Deori & Dimasa & Gloss \\
\hline mu-dza & ma-fI & 'one' \\
\hline mo-honi & ma-gin/ma-gnI & 'two' \\
\hline mon-da & $\begin{array}{l}\text { ma-ktham }(/ g / \\
\text { undergoes change in } \\
\left.\text { gtham due to }^{\text {ham }} \text { prefixation }\right)\end{array}$ & 'three' \\
\hline$m \sigma-t \int I$ & ma-bri & 'four' \\
\hline mu-muwa & ma-bwa & 'five' \\
\hline$m u-t y u$ & ma-do? & 'six' \\
\hline$m \sigma-t$ In & 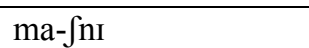 & 'seven' \\
\hline$m v-t g e$ & ma-dzai & 'eight' \\
\hline mo-dvgv & $\begin{array}{l}\text { ma- } \int \mathrm{k}^{\mathrm{h}} \mho\left(/ \int \mathrm{g} /\right. \\
\text { undergoes change in } \\
\int \mathrm{g} v \text { as }-\int \mathrm{k}^{\mathrm{h}} \mho \text { due to } \\
\text { prefixation of ma- })\end{array}$ & 'nine' \\
\hline mu-dvga & ma-dzI & 'ten' \\
\hline
\end{tabular}

Numerals in bare forms can be used for counting humans while the $\mathrm{gV}$ - forms in Deori are used for counting the same. 
32 / Patterns of sound...

Table 18:Classifier $\mathrm{gV}$ - for counting numerals (generic) in Deori and Dimasa

\begin{tabular}{|c|c|c|}
\hline Deori & Dimasa & Gloss \\
\hline godza & $\int \mathrm{I} / \int \mathrm{e}$ & 'one' \\
\hline gohoni & gnI & 'two' \\
\hline gojda & $\mathrm{gt}^{\mathrm{h}} \mathrm{am}$ & 'three' \\
\hline gotfI & brI & 'four' \\
\hline $\mathrm{vt}^{\mathrm{h}}$ onpetfa & bwa & 'five' \\
\hline $\mathrm{vt}^{\mathrm{h}} \mathrm{u}$ petfa godza & do? & 'six' \\
\hline$v^{\mathrm{t}^{\mathrm{h}}}$ jpetfa gohoni & $\int \mathrm{nI}$ & 'seven' \\
\hline djoikın & dzai & 'eight' \\
\hline dzorkın gudza & $\int g u$ & 'nine' \\
\hline$v \mathrm{t}^{\mathrm{h}}$ onpekınI & dzI & 'ten' \\
\hline
\end{tabular}

Numeral classifiers are also based from nouns and bound roots in Dimasa whereas in Deori, they are bound morphemes ( $t_{I}-/ g v$ for round objects, $h a-$ $/ g v-/ k v-/ t^{-}$for flat objects, le-/ke-/gv-/dvk- for chopped objects, $g v$ - for human and non-humans, $d v$ - for humans and $m V$ - for generic nouns).

\subsection{Other morphological features}

This section briefly compares similar morphemes that carry nominal and verbal features in both Deori and Dimasa. It also discusses borrowing as a result of areal contact among these two languages.

\subsubsection{Relativizer -ja}

-ja is the relativizing suffix in both the languages deriving verbs to nouns. However, it occurs alone with the stem in Deori whereas it occurs with the nominalizing - $b a$ in Dimasa (in singular nouns).

Table 19:-jainDeori and Dimasa

\begin{tabular}{|l|l|l|}
\hline Deori & Dimasa & Gloss \\
\hline porI-ja & p $^{\mathrm{h}}$ UrI-ja-ba & 'student' \\
\hline akI-ja & $\mathrm{ak}^{\mathrm{h}} \mathrm{I}-\mathbf{j a}$-ba & 'painter' \\
\hline
\end{tabular}

\subsubsection{Nominalizer- $b a$}

$-b a$ is the nominalizing suffix attached to verbs and adjectives for noun derivation in both Deori and Dimasa as illustrated in Table 20:

Table 20: -bainDeori and Dimasa

\begin{tabular}{|l|l|l|}
\hline Deori & Dimasa & Gloss \\
\hline giba-ba & gba-ba & 'vomiting' \\
\hline ka-ba & k'a-ba & 'bitterness' \\
\hline sa-ba & lim-baJa-ba (sickness & 'disease' \\
\hline
\end{tabular}

\begin{tabular}{|l|l|l|}
\hline & and pain) & \\
\hline dze-ba & hadzaI-ba & 'birth' \\
\hline
\end{tabular}

\subsection{3 bV-and $\mathrm{pV}$ - in kinship}

Most of the kinship nouns common in both the languages have $\mathrm{pV}$ - forms for terms of reference, and sometimes loses its feature, while Dimasa retains the voiced bV- counterparts as shown in Table 21.

Table 21:bV- andpV- in kinship In Deori and Dimasa

\begin{tabular}{|c|c|c|}
\hline Deori & Dimasa & Gloss \\
\hline be-be & bu-bI & 'elder sister' \\
\hline pI-sa & $\mathbf{b} \int \mathrm{a} / \mathbf{b} \boldsymbol{2} \int \mathrm{a}$ & 'son' \\
\hline pI-sasI & 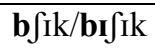 & 'daughter' \\
\hline tyjã & baudzI & 'sister-in-law' \\
\hline
\end{tabular}

2.3.4 gV-prefix in adjective

Noun-like adjectives have the $\mathrm{gV}$ - forms in Dimasa while Deori has the loss of the use of $\mathrm{gV}$ forms for the same as exemplified in Table 22:

Table 22:gV-prefix in adjective inDeori and Dimasa

\begin{tabular}{|c|c|c|}
\hline Deori & Dimasa & Gloss \\
\hline ty & gdzv/godzo, dzv & 'high' \\
\hline $\mathrm{ka}$ & gk $^{\mathrm{h}} \mathrm{a} / \mathbf{g}^{2} \mathrm{k}^{\mathrm{h}} \mathrm{a}, \mathrm{k}^{\mathrm{h}} \mathrm{a}$ & 'bitter' \\
\hline $\mathrm{p}^{\mathrm{h}_{\mho}}$ & $\mathbf{g}^{\prime} \mathrm{p}^{\mathrm{h}} \mho, \mathrm{p}^{\mathrm{h}} \mho$ & 'white, silver' \\
\hline $\mathrm{p}^{\mathrm{h}_{\sigma}}$ & gdzav/gәdzav, dzav & 'red, gold' \\
\hline $\mathrm{t}^{\mathrm{h}} \mathrm{II}$ & 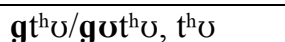 & 'deep' \\
\hline
\end{tabular}

\subsubsection{Pronouns}

Word final deletion of mostly nasals as well as syllable deletion in case of pronouns in Deori is a common feature unlike the retention feature in Dimasa.

Table 23:Personal Pronoun in Deori and Dimasa

\begin{tabular}{|c|c|c|}
\hline Deori & Dimasa & Gloss \\
\hline$\tilde{\mathrm{A}}$ & a) & 'I' \\
\hline no & nin & 'you' \\
\hline $\mathrm{ba}$ & bo & 'he/she/it' \\
\hline dzov & dsin & 'we' \\
\hline nov & nI $\int \mathbf{I}$ & 'you(pl)' \\
\hline
\end{tabular}




\begin{tabular}{|l|l|l|}
\hline bav & bonfi & 'they' \\
\hline
\end{tabular}

Indefinite pronouns such as,bosina $\sim \boldsymbol{h}$ Ina 'which' as shown in Table 24, traces the distant innovation between Deori(bosina)and the Dijuwa dialect of Dimasa (hına), which needs deeper research in terms of the dialectal diachrony of Deori and Dimasa.

Table 24:Indefinite Pronoun inDeori and Dimasa

\begin{tabular}{|c|c|c|}
\hline Deori & Dimasa & Gloss \\
\hline sa & fre & 'who' \\
\hline samagudza & freba & 'someone' \\
\hline $\begin{array}{l}\text { ḑIkunødøksa } \\
\text { (Assametized) }\end{array}$ & a Jaba & 'anyone' \\
\hline $\begin{array}{l}\text { sobre } \\
\text { (Assametized) }\end{array}$ & $\mathrm{k}^{\mathrm{h}} \mathrm{s} 1 \mathrm{p}$ & 'everyone' \\
\hline doksakedza & $\int \mathrm{a} v \int \mathrm{I}$ & 'no one' \\
\hline zibare & frebaleI & 'whoever' \\
\hline damdI & nadI & 'what' \\
\hline damagudza & $\begin{array}{l}\int \mathrm{maba} / \\
\int \mathrm{mabag} \partial \mathrm{d} a\end{array}$ & 'something' \\
\hline ZIboho & bək ${ }^{\text {halıba }}$ & 'sometimes' \\
\hline doms & bək ${ }^{\text {halI }}$ & 'when' \\
\hline bohos & bra & 'where' \\
\hline danoI & nadinI & 'why' \\
\hline $\begin{array}{l}\text { bofale } \\
\text { (Assame- } \\
\text { tized) }\end{array}$ & bdzaygde & 'which way' \\
\hline bosina & $\begin{array}{l}\text { Jombo (hına, } \\
\text { Dijuwa } \\
\text { dialect) }\end{array}$ & 'which one' \\
\hline dakın & bde & 'how' \\
\hline bomagodzaho & brabei & 'somewhere' \\
\hline
\end{tabular}

The phonological alternations in these pronouns are seen to be highly occurring in Deori and Dimasa as discussed in the previous sections. Besides, it is interesting to observe that the quantifier godza tends to be productive in Deori when attached with the indefinite pronominals for the words meaning 'someone', something', 'somewhere' which has the negative counterpart kedza for 'no one'. On the contrary, Dimasa uses only the affirmative quantifier as gadza for the same meanings, while the negated form is absent.

\subsubsection{Nouns $d u b u$ and $d \xi I b v$}

While Deori uses dzIfor 'water', Dimasa uses dito mean the same. Hence, dis ̃̃and adirrmay have been shared words from Dimasa during the development of the Deori language.

The oppositeness in shared semanticity in the word for 'snake' is interesting since the morpheme drin Deoridubo, which tends to undergo vowel harmony,also means the Dimasa 'water' while the morpheme dzrin Dimasadzıbuagain in isolation means the Deori 'water' as shown in Table 25.

Table 25: Other nouns inDeori and Dimasa

\begin{tabular}{|c|c|c|c|}
\hline Deori & Dimasa & Gloss & $\begin{array}{l}\text { Semantic } \\
\text { feature }\end{array}$ \\
\hline dıs̃̃ & didik & 'pitcher' & $\begin{array}{l}\text { di 'water' } \\
\text { in Dimasa }\end{array}$ \\
\hline adıIII & didap & 'mud' & $\begin{array}{l}\text { di 'water' } \\
\text { in Dimasa }\end{array}$ \\
\hline dubu & $\begin{array}{l}\text { dzıbo } \\
\text { (dzobo, } \\
\text { Hawar, } \\
\text { Dijuwa } \\
\text { dialects) }\end{array}$ & 'snake' & $\begin{array}{l}\text { Umlaut/Vowel } \\
\text { harmony and } \\
\text { shared } \\
\text { semantics }\end{array}$ \\
\hline
\end{tabular}

\subsubsection{Negation $-j a$}

$-j a$ is homophonous in both the languages since it functions for both relativization and negation of the verb roots (although Deori has the lexical $t s a / z a$ to negate adjectives, while Dimasa has -ja for both verbs and adjectives).

Table 26:Negation -ja inDeori and Dimasa

\begin{tabular}{|l|l|l|}
\hline Deori & Dimasa & Gloss \\
\hline sadv-ja-ba & grao-fi & 'disagreement' \\
agree-NEG- & word-same & \\
NMZ & dza-ja-ja-ba & \\
& become- & \\
& NEG-RLVZ- & \\
& NMZ & \\
\hline
\end{tabular}

\subsection{Borrowings}

Borrowing occurs mostly from the Eastern IndoAryan languages, such as Assamese in case of Deori and both Assamese and Bengali for Dimasa. However, they are nativized in both the languages (voicing, aspiration in Dimasa and no aspiration, voicing in Deori). 
34 / Patterns of sound...

Table 27:Borrowings inDeori and Dimasa

\begin{tabular}{|l|l|l|}
\hline Deori & Dimasa & Gloss \\
\hline $\begin{array}{l}\text { bih } \\
\text { Assamese) }\end{array}$ & $\begin{array}{l}\text { bI } \\
\text { (Bangla) }\end{array}$ & $\begin{array}{l}\text { 'poison' (>Eastern } \\
\text { Indo-Aryan) }\end{array}$ \\
\hline hontıra & hondra & $\begin{array}{l}\text { 'orange' (>Hindi: } \\
\text { Indo-Aryan, } \\
\text { santra) }\end{array}$ \\
\hline $\begin{array}{l}\text { modorI/ } \\
\text { somata }\end{array}$ & fok ${ }^{\text {hrem }}$ & $\begin{array}{l}\text { 'guava' (>Khasi: } \\
\text { Austro-Asiatic, } \\
\text { sohprem) }\end{array}$ \\
\hline
\end{tabular}

3. Sociolinguistic Observations

Throughout the analysis, it was observed that language loss is more prominent in Deori while retention is seemingly found in Dimasa due to several factors: Deori has clipped forms and simplified syllable structure than Dimasa, besides higher monophthongisation and word-final deletion. Again, loan words are highly common in the former than the latter due to contact with the neighbouring language Assamese, which is a dominant language in the Deori area surrounding the Brahmaputra river valley even though there are other Tibeto-Burman languages in contact such as Mising and Boro, and Tai-Kadai languages like Khamti. There is no language dominance in case of Dimasa(even if the lingua franca are Indo-Aryan (Assamese in Nagaon and KarbiAnglong, Bengali in the Barak valley), pidgin Haflong Hindi in DimaHasao hill district and a creole Nagamese in the state of Nagaland), since the majority of Dimasa speakers live in the hill district, DimaHasao, which is less accessible from the plains of Assam, with nearly 12 ethnic tribes from the Kuki-Naga group of the TibetoBurman family.

Further, the data collected for the present study is from Dibongiya dialect which is perhaps the only living speech community of Deori, while the other dialects are either extinct or nearly extinct. On the contrary, all the dialects of Dimasa are still spoken at home, although Hasao dialect was chosen for the Dimasa comparison here.

Parental and the younger generations among Deori are losing the use of everyday words like, kinship terms (e.g.,: addressing 'grandfather'), numerals (counting known till ' 4 '), colour terms (basic colour 'black' replaced with Assamese loan 'koliya'). On the other hand, both the generations still retain and use the everyday words in case of Dimasa speakers. New words have also emerged in Dimasa, as a result, and underwent semantic drift, as in, hagrafa'caveman/jungle man'>'insurgent groups', $\operatorname{maI}^{h^{h}} \sigma d_{I}$ 'rice water bubbles' > 'Hmar community (although Dimasa native name is Thangumsa), hilaI'canon' > 'rifle', and so on.

However, both the language speakers have a positive attitude towards their language. Several attempts have been made across the years to revitalize both the languages from the speech communitiesbut results on textbooks and material productions have been a gradual process, andpartially successful in recent times.

\section{Conclusion}

The study revealed that vowel alternation occurs irregularly across these two languages. Deori has the monophthongization of the sounds $/ \mathrm{o} /$ and $/ \mathrm{v} /$ that are present in Dimasa as diphthong as in /av/. Syllable alternation is seen in few cases of shared innovation in both the languages. Deori has the absence of aspiration in sounds shared with those having aspiration in Dimasa. Deletion in the initial and the final word positions/syllables are common for shared words in Deori while only initial deletion has been found among the cognates in Dimasa. Deori has more simplified syllable structure than Dimasa. It also discusses the counting system and the use of borrowing in both the languages and thereby, studies their sociolinguistic context of language loss and retention.Thus, it can be concluded that language loss is more prominent in Deori while retention is seemingly found in Dimasa. However, with the degree of shift in Deori and vulnerability of Dimasa, documentation is thus utmost necessary in the present context.

Abbreviations

NEG Negation

NMZ Nominalizer

RLVZ Relativizer

\section{References}

Barman, N.K. 2007. The Queens of Cachar or Herambo and The History of the Kachchhari. Barkhola: N.K. Barman. 
Burling, R.2012. 'The Stammbaum of Boro-Garo' In Gwendolyn Hyslop, Stephen Moreyand Mark W. Post, (Eds.)North East Indian Linguistics, Volume 4. New Delhi: CambridgeUniversity Press: 21-35.

Census of India. 2001. www.censusindia.gov.in. (Accessed on June 30, 2019).

Eberhard, David. M; Simons, Gary F. \&Fennig, Charles D. (Eds.). 2019. Ethnologue: Languages of the World. Twenty-second edition. Dallas, Texas: SIL International. Downloaded from http://www.ethnologue.com on July 1, 2019.

Jacquesson, F. 2005. Le Deuri: langue tib tobirmaned'Assam. Collection

linguistique. Paris: Peeters.

Jacquesson, F. 2008. A Dimasa Grammar. http://brahmaputra.vjf.cnrs.fr/bdd/IMG/pdf/Di masa_Grammar-2.pdf. (Accessed on July 1, 2019).

Longmailai, M. 2014. The Morphosyntax of Dimasa. Unpublished PhD Thesis. Department of Linguistics, North-Eastern Hill University, Shillong.

Map of Assam. 2019. Downloaded from www.mapsofindia.com/maps/assam/assamdistrict.html on June 30, 2019.

Nath, A. K. 2012. Sound Change in Deori: A Descriptive Account. Journal of Universal Language. 13 (2): 65-89.

Post, Mark W. and Robbins Burling. 2017. "The Tibeto-Burman languages of Northeast India." In Randy J. LaPolla and Graham Thurgood, Eds. The Sino-Tibetan languages (2nd edition). United Kingdom, Routledge: 213242.

Singha, D. Th. 2001. The Phonology \& Morphology of Dimasa. M.Phil Dissertation. Silchar: Assam University.

Singha, D. Th. 2007. Introduction to Dimasa Phonology. Guwahati: DVS Publishers. 